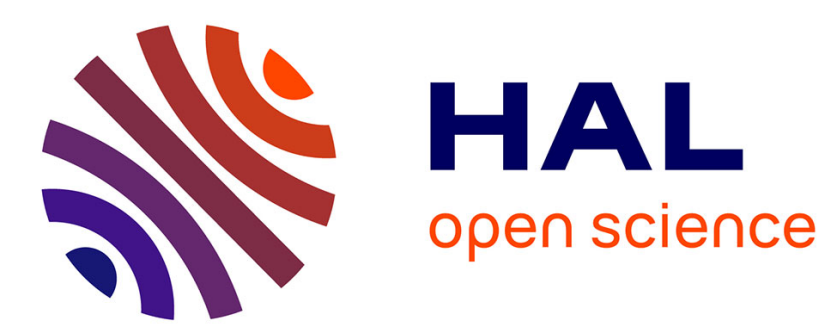

\title{
Elements in the interpretation of Platinum electrode potentials in biological treatment
}

\author{
A. Heduit, Daniel R. Thevenot
}

\section{To cite this version:}

A. Heduit, Daniel R. Thevenot. Elements in the interpretation of Platinum electrode potentials in biological treatment. Water Science and Technology, 1992, 26 (5 - 6), pp.1335 - 1344. hal-01179836

\section{HAL Id: hal-01179836 \\ https://hal.science/hal-01179836}

Submitted on 23 Jul 2015

HAL is a multi-disciplinary open access archive for the deposit and dissemination of scientific research documents, whether they are published or not. The documents may come from teaching and research institutions in France or abroad, or from public or private research centers.
L'archive ouverte pluridisciplinaire HAL, est destinée au dépôt et à la diffusion de documents scientifiques de niveau recherche, publiés ou non, émanant des établissements d'enseignement et de recherche français ou étrangers, des laboratoires publics ou privés. 


\title{
ELEMENTS IN THE INTERPRETATION OF PLATINUM ELECTRODE POTENTIALS IN BIOLOGICAL TREATMENT
}

\author{
A. Heduit* and D. R. Thevenot** \\ * Centre National du Machinisme Agricole, du Génie Rural, des Eaux et des Forêts \\ (CEMAGREF), Division Qualité des Eaux, 14 avenue de Saint-Mandé, 75012 Paris, \\ France \\ ** Université Paris XII, Val de Marne (U.P.V.M.), U.F.R. de Sciences et de \\ Technologie, Laboratoire de Bioélectrochimie et Analyse du Milieu (LABAM), Avenue \\ de Général de Gaulle, 94010 Creteil Cedex, France
}

\begin{abstract}
The zero current potential of a platinum electrode in a biological medium (wastewater, activated sludge) is strongly dependent on the surface characteristics of the metal. It is also influenced by $\mathrm{pH}$ (probably $\mathrm{Pt} / \mathrm{PtO}$ system), dissolved oxygen $\left(\mathrm{O}_{2} / \mathrm{OH}^{-}\right.$system), and ionic forms of nitrogen $\left(\mathrm{NO}_{2}{ }^{-} / \mathrm{NH}_{4}{ }^{+}\right.$and $\mathrm{NO}_{3}^{-} / \mathrm{NO}_{2}^{-}$systems).

The experimental values of the coefficients relating the stabilized potential of a platinum electrode to the logarithm of the concentration of the elements under consideration (Nernst equations) are significantly different from the thermodynamic coefficients corresponding to each reaction. The platinum is thus not in equilibrium with the dissolved redox reactants and is likely subject to mixed potentials in which the adsorbed components play an important role.
\end{abstract}

\section{KEY WORDS}

Redox potential, platinum electrode, activated sludge, instrumentation, control.

\section{INTRODUCTION}

The platinum electrode zero current potential has for several years exerted a strong attraction in France as a control parameter for the nitrification/denitrification processes in biological wastewater treatment plants (CHARPENTIER et al., 1987; HEDUIT et al., 1988; CHARPENTIER et al., 1989; VIRLOGET, 1991). Its use for controlling the enhanced biological phosphorus removal has also been envisioned (KOCH and OLDHAM, 1985). This very simple measurement parameter offers the advantages of being common to all stages of treatment and of requiring no calibration. However, wastewaters contain a multitude of components which, by being either in solution or adsorbed onto the electrode, can influence its response. Furthermore, GOLDSMITH et al. (1984) and HEDUIT et al. (1987) have noted disparity among stabilized potentials taken from different platinum electrodes immersed in the same activated sludge.

Progress in understanding the origin of these potentials is thus essential if they are ever to be in use for controlling treatment processes. 
The objective of this work was to study the influence of various treatments of the metal on the voltage delivered by a platinum electrode in activated sludge, as well as to point out the effects of $\mathrm{pH}$, dissolved oxygen, and ionic forms of nitrogen on this potential.

\section{MATERIAL AND METHODS}

\section{Pilot Plant}

The $30 \mathrm{l}$ activated sludge plant has been described in an earlier paper (HEDUIT et al., 1988) : the organic load (Viandox) and the hydraulic load (tap water) are injected separately. The daily load is fed in 48 equal doses (one each half-hour). The aeration cycle consists of a half-hour air diffusion on followed by a half-hour off. Agitation operates during the aeration phases and during the feeding phases.

The average experimental conditions were as follows .

Volumic loading : $0.37 \mathrm{~g}$ BOD.1 $\mathrm{l}^{-1} . \mathrm{d}^{-1}$

Sludge loading : $0.096 \mathrm{~g}$ BOD.g MLVSS ${ }^{-1} . \mathrm{d}^{-1}$

Mixed Liquor Suspended Solids : $4.8 \pm 0.5 \mathrm{~g} . \mathrm{l}^{-1}$ (with $80 \%$ MLVSS)

$\mathrm{pH}: 7.6 \pm 0.2$

\section{Measurement Cell}

This is a 2-litre rectangular PVC cell that can accommodate 10 electrodes. It is generally placed on a magnetic agitator and the liquid is stirred with a teflon bar.

\section{Electrochemical Measurements}

\section{$\underline{\text { Materials }}$}

The characteristics of the platinum electrodes are presented in table 1 . The reference electrodes were INGOLD XEROLYT electrodes.

Table 1. Characteristics of the Platinum Electrodes

\begin{tabular}{|c|c|c|c|c|}
\hline TRADEMARK & TYPE & SHAPE & $\begin{array}{c}\text { SIZE } \\
\mathrm{mm}\end{array}$ & $\begin{array}{c}\text { AREA } \\
\text { cm? }\end{array}$ \\
\hline INGOLD & Pt 805 & ring & $\begin{array}{l}\phi=6 \\
\mathrm{n}=3\end{array}$ & 0.56 \\
\hline PROLABO & home made & wire & $\begin{array}{l}\phi=0.5 \\
\mathrm{~L}=30\end{array}$ & 0.47 \\
\hline
\end{tabular}

The measurement electrodes, along with their associated common reference electrode, were connected to a HEWLETT PACKARD HP 3421A automatic data acquisition system (central processor equipped with a 10-channel multiplexer card, internal resistance $10^{10} \mathrm{ohms}$, accuracy at the $3 \mathrm{~V}$ range : $0.3 \mathrm{mV})+\mathrm{HP}-41 \mathrm{CV}$ calculator $+82162 \mathrm{~A}$ thermal printer $+82161 \mathrm{~A}$ microcassette recorder.

Oxygen concentrations were measured with YSI 57 oxygen meters linked to the HP central processor.

pH was measured using combined INGOLD XEROLYT electrodes linked to high input impedance millivoltmeters (KNICK 646) connected to the data acquisition unit. 


\section{Platinum Electrode Treatment}

Three different electrode treatments were tested.

\section{Thermal Treatment}

This treatment is intended to oxidize impurities which have been fixed or adsorbed onto the metal surface. It is reserved for the PROLABO electrodes that have been specially constructed with glass having the same coefficient of thermal expansion as the platinum wire. The platinum was brought to red heat for several seconds in the blue flame of a butane torch. The metal was then cooled under running distilled water, where it may be kept for several tens of minutes.

\section{Polishing}

This treatment increases the roughness of the platinum surface (and thus probably also the electron exchange rates). The polishing was performed using bands of powdered abrasive (granularity 3 and $0.3 \mu \mathrm{m}$ ) fixed onto a plastic support (TACUSSEL BSC 3 and BAO 3 abrasive bands). The electrodes were then rinsed in distilled water and wiped with soft paper.

\section{Adsorption of Sulfides}

In the presence of sulfide ions, a layer of platinum sulfide is formed (WHITFIELD, 1974). This test is intended to simulate the behaviour of platinum electrodes that have been immersed in activated sludge containing sulfides (under conditions of anoxia or anaerobiosis). The electrode first underwent a thermal or mechanical treatment and was then immersed (at red heat, if pretreated thermally) in a solution of $0.1 \mathrm{M} \mathrm{Na}_{2} \mathrm{~S}$ (MERCK pro analysis). It was then rinsed and kept in distilled water.

\section{Test Procedures}

All zero current potential $\left(\mathrm{E}_{\mathrm{H}}\right)$ values have been averaged for 2 or 3 indicating electrodes and referred to the Normal Hydrogen Electrode (NHE). Unless otherwise specified, the recorded potentials were measured after a stabilization time of 30 minutes (inside the measurement cell).

The influence of platinum treatment on electrode potential was evaluated either using sludge extracted from the pilot plant that was first aerated and then stirred without aeration in the measurement cell, or else directly in sludge of the pilot plant's aeration basin that was subjected to cyclical variations of potential (aeration and feeding cycles).

The influence of $\mathrm{pH}$ on platinum electrode was studied using treated water that was kept at $23^{\circ} \mathrm{C}$ $\pm 0.5^{\circ} \mathrm{C}$ in the thermostated measurement cell with the variations of $\mathrm{pH}$ being obtained by injecting air or carbon dioxide gas. Another series of experiments was conducted using treated water from the treatment plant of a rural town (MAINCY - Seine et Marne), with pH variations obtained by adding $1 \mathrm{M}$ sulfuric acid (MERCK pro analysis) and $1 \mathrm{M}$ sodium hydroxide (PROLABO Normapur).

The influence of dissolved oxygen concentration on platinum electrode potential was studied in the pilot plant : air flows were modified from one cycle to another and the stabilized electrode potentials and dissolved oxygen concentrations were recorded at the end of the aeration cycle. Four series of experiments were conducted at intervals of several weeks.

The influence of mineral forms of nitrogen was studied in a phosphate buffer solution at $\mathrm{pH} 7$ (PROLABO Normadose), saturated in dissolved oxygen, and maintained at $23 \pm 0.5^{\circ} \mathrm{C}$ in the measurement cell. 
$\mathrm{NaNO}_{2}$ and $\mathrm{NaNO}_{3}$ or $\mathrm{NH}_{4} \mathrm{Cl}$ (PROLABO Normapur) were added in order to vary the $\left[\mathrm{NO}_{2}^{-}\right] /\left[\mathrm{NH}_{4}{ }^{+}\right]$and $\left[\mathrm{NO}_{3}^{-}\right] /\left[\mathrm{NO}_{2}^{-}\right]$ratios. To conform to real-world conditions in water treatment, the concentration of $\mathrm{NO}_{2}^{-}-\mathrm{N}$ was fixed at $0.15 \mathrm{mg} \cdot \mathrm{l}^{-1}$ while the concentrations of ammoniacal and nitric forms were varied by order of magnitude between 0.27 and $270 \mathrm{mg}$ $\mathrm{NH}_{4}^{+}-\mathrm{N}^{-1} \mathrm{l}^{-1}$ and 0.1 and $100 \mathrm{mg} \mathrm{NO}_{3}{ }^{-}-\mathrm{N}_{1} \mathrm{l}^{-1}$, respectively. The measurements were made after a stabilization time of 24 hours and the composition of the solution was verified after each measurement (TECHNICON Analyzer).

\section{RESULTS AND DISCUSSION}

\section{Influence of platinum treatment on electrode behaviour}

Figure 1 shows the typical evolution of electrode potentials, according to the initial treatment of the metal, in nitrifying activated sludge that was first aerated then stirred without aeration.

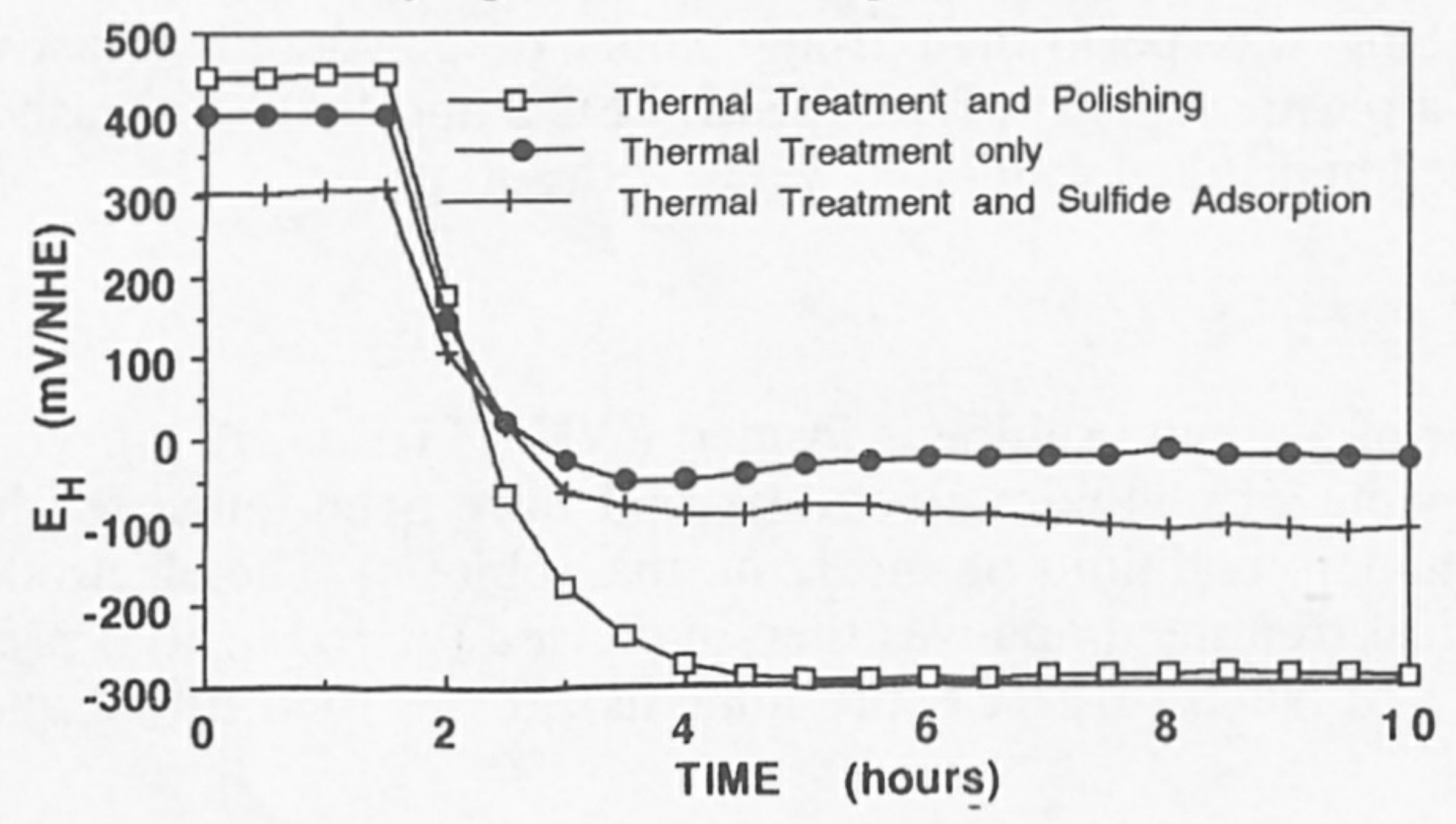

Fig. 1. Typical evolution of platinum electrode potentials in activated sludge first aerated, then kept under agitation without aeration

During the aerated phase, average stabilized potentials of polished platinum electrodes were approximately $+450 \mathrm{mV} / \mathrm{NHE}$. Under the same conditions, potentials of electrodes that had been in contact with sulfides were lower, at around $150 \mathrm{mV}$, while potentials of thermally treated electrodes fell between these two levels.

When aeration was stopped, potentials dropped after the dissolved oxygen disappeared. After several hours, when potentials had once again stabilized, the polished electrodes presented the lowest values.

The deviations among the stabilized voltages of platinum electrodes that have had the same treatment (thermal, thermal and polishing, thermal and $\mathrm{Na}_{2} \mathrm{~S}$ adsorption) were generally quite small (less than $10 \mathrm{mV}$ ) in an aerobic medium. In an anoxic medium, these deviations were often greater and could reach $100 \mathrm{mV}$.

Figures 2 and 3 show the typical evolution of platinum electrode potentials in the pilot plant's aeration basin (subjected alternately to sequences of aeration and anoxia).

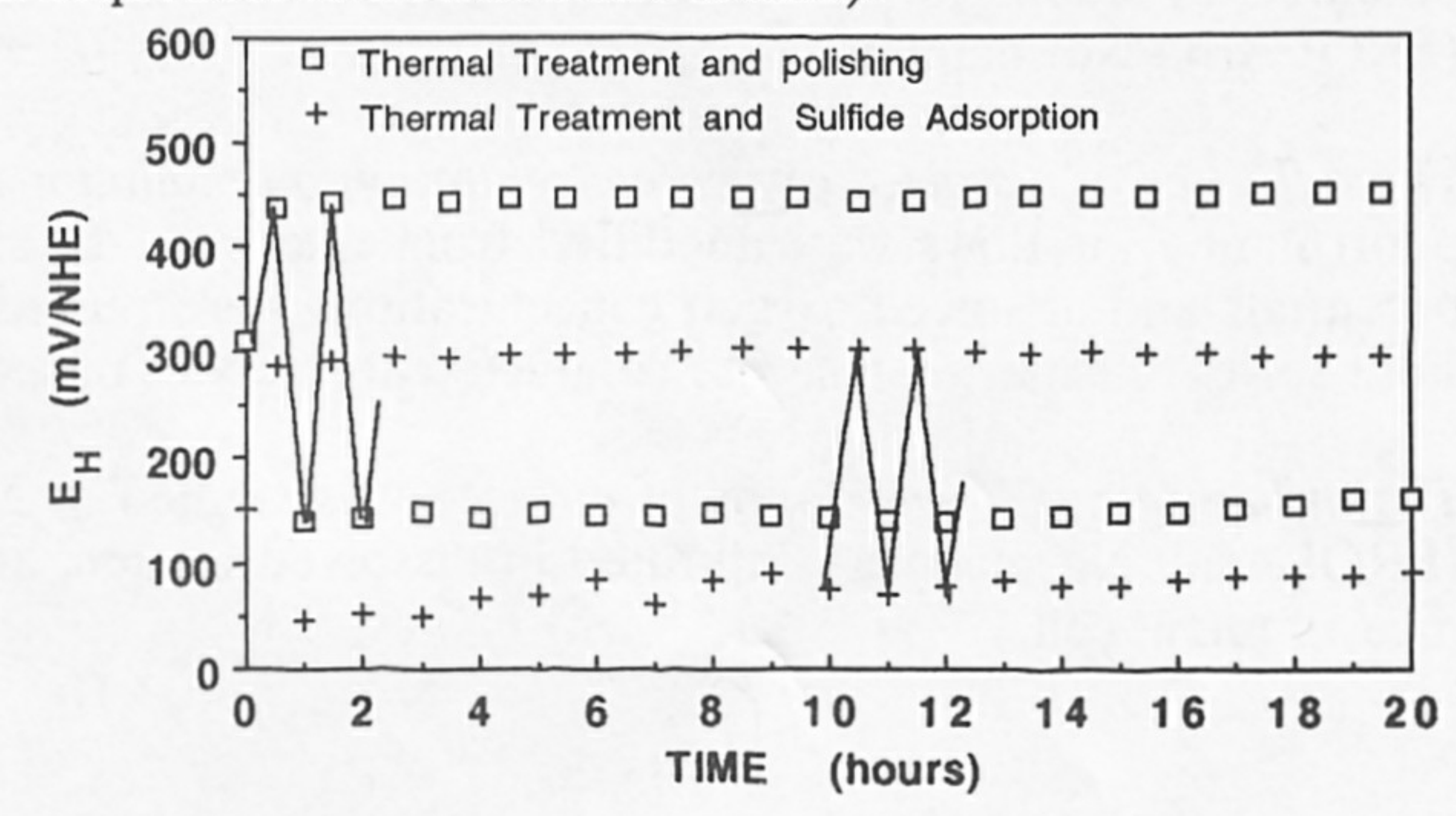

Fig. 2 - Pilot plant : Typical evolution of platinum electrode potentials : minimum and maximum values at the end of the sequences of anoxia and aeration 


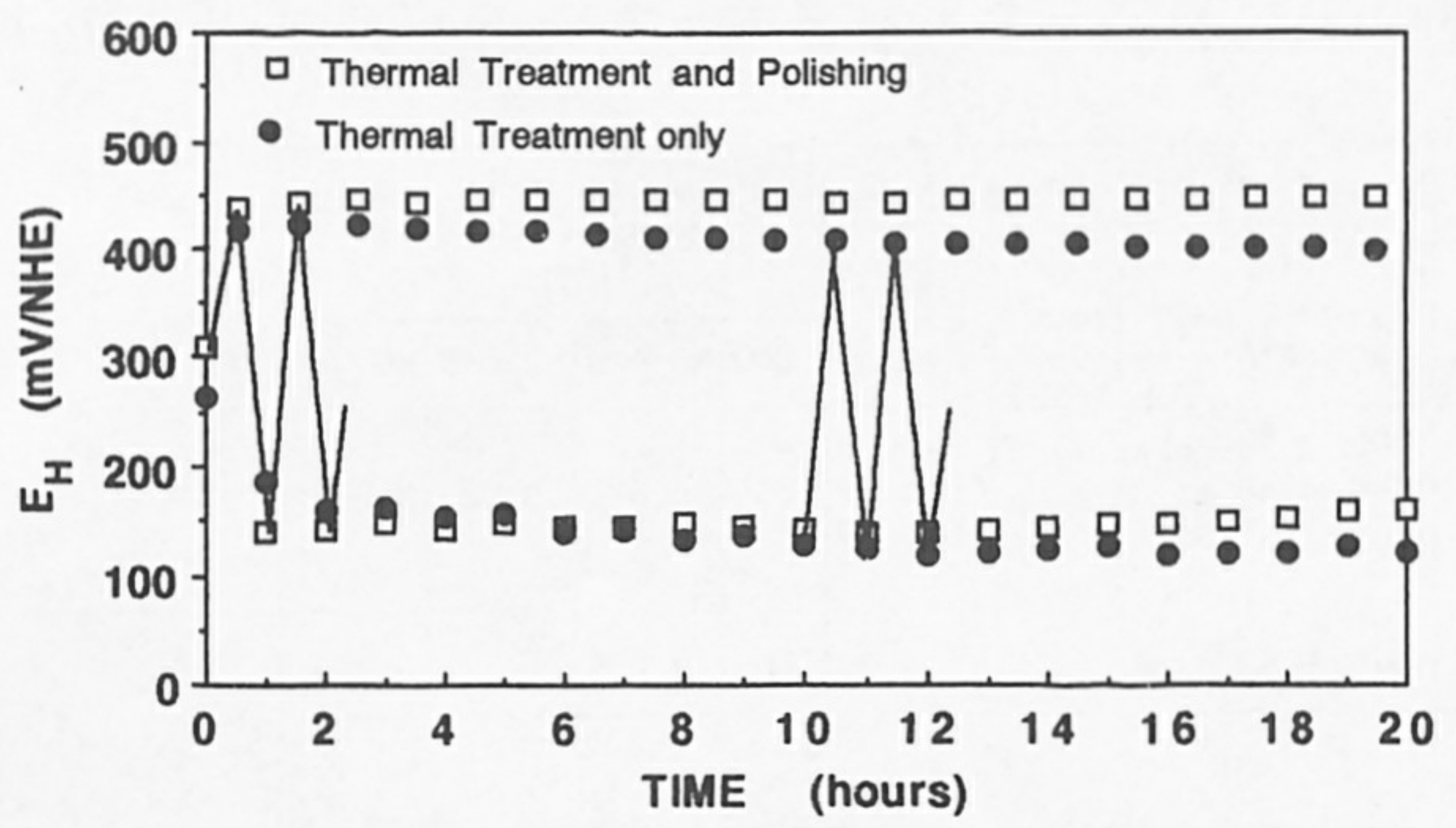

Fig. 3 - Pilot plant : Typical evolution of platinum electrode potentials : minimum and maximum values at the end of the sequences of anoxia and aeration

At the end of the aeration periods (i.e., in the presence of dissolved oxygen), the polished electrodes presented the highest potentials, the sulfided electrodes had the lowest, and the heattreated electrodes fell in between. The potential values reached were close to those seen during the aerated phase in the preceding experiments.

When the electrodes had undergone thermal treatment, a drift (of about 1 millivolt per hour) was observed in the potentials reached at the end of the aeration period. This was probably a consequence of gradual and uncontrolled adsorption of chemical substances onto the metal that had previously been activated by being annealed. The stability of potentials on polished platinum electrodes under the same conditions may be due to initial neutralizing of the adsorption sites on the platinum by substances deposited by the abrasive paper. With the heat-treated electrodes, several hours were needed for the value of the potential at the end of the period of anoxia to stabilize. The amplitude of potential variations was smallest for those electrodes that had undergone sulfide adsorption. The previous observations concerning the dispersion of stabilized potentials on identically pre-treated electrodes continue to apply. These experiments bring out the problem that is posed by platinum electrode potential measurements in activated sludge : the platinum does not behave like an inert metal; depending on whether the electrode has first been polished, annealed, or in contact with sulfides, its behaviour will be quite different, resulting in evident difficulties for the use of this measure to control biological purification plants.

\section{Origin of the Potential}

The influences of $\mathrm{pH}$, dissolved oxygen, and ionic forms of nitrogen on platinum electrode were examined.

\section{$\mathrm{pH}$}

Figure 4 shows the influence of $\mathrm{pH}$ on platinum electrode potential within treated water from the pilot plant at $23 \pm 0.5^{\circ} \mathrm{C}$.

Fig. 4. Potential vs. $\mathrm{pH}$ at $23^{\circ} \mathrm{C}$ in treated water from the pilot plant

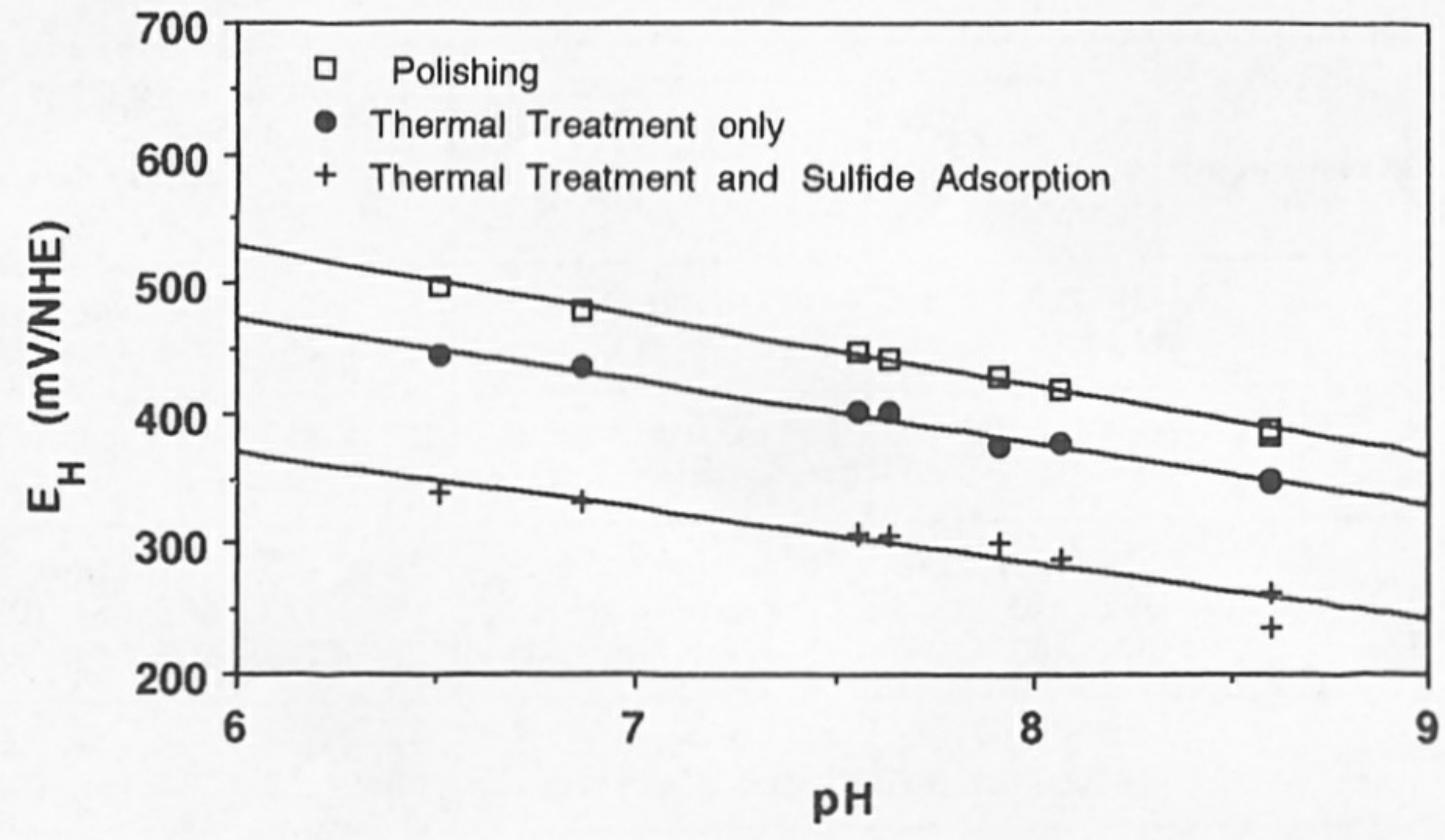

The data from the various measurements that were made are summarized in table 2. 
Table 2. Results and Analytical Parameters for Potential vs. pH including equations 1 - 4

\begin{tabular}{|c|c|c|c|c|c|c|c|c|c|c|}
\hline \multirow{2}{*}{$\begin{array}{l}\text { Origin } \\
\text { of } \\
\text { water }\end{array}$} & \multirow{2}{*}{$\begin{array}{c}\text { Type } \\
\text { of } \\
\text { electrodes }\end{array}$} & \multirow[t]{2}{*}{ Treatment } & \multirow{2}{*}{$\begin{array}{c}\text { Equations of } \\
\text { regression } \\
\text { lines } \\
\text { EH=A-B pH } \\
(\mathrm{mV} / \mathrm{NHE})\end{array}$} & \multirow{2}{*}{$\left|\begin{array}{c}\text { Ref. } \\
\text { of } \\
\text { equa- } \\
\text { tions }\end{array}\right|$} & \multirow[t]{2}{*}{$\mathrm{n}$} & \multirow[t]{2}{*}{$r^{2}$} & \multicolumn{4}{|c|}{$\begin{array}{l}\text { Results of effluent } \\
\text { analysis (mg. } \mathrm{l}^{-1} \text { ) }\end{array}$} \\
\hline & & & & & & & $C O D$ & $\mathrm{NH}_{4}^{+}-\mathrm{N}$ & $\mathrm{NO}_{2}{ }^{-}-\mathrm{N}$ & $\mathrm{NO}_{3}^{-}-\mathrm{N}$ \\
\hline $\begin{array}{l}\text { PILOT } \\
\text { PLANT }\end{array}$ & $\begin{array}{l}\text { INGOLD Pt805 } \\
\text { PROLABO } \\
\text { PROLABO }\end{array}$ & $\begin{array}{l}\text { polishing } \\
\text { thermal } \\
\text { Th + } \\
\text { sulfide ads }\end{array}$ & $\begin{array}{l}E H=852-54 p H \\
E H=764-48 p H \\
E H=628-43 p H\end{array}$ & $\begin{array}{l}1 \\
2 \\
3\end{array}$ & $\begin{array}{l}8 \\
8 \\
8\end{array}$ & $\begin{array}{l}0.98 \\
0.99 \\
0.89\end{array}$ & 83 & 0.6 & 0.02 & 0.3 \\
\hline $\begin{array}{l}\text { MAINCY } \\
\text { PLANT }\end{array}$ & INGOLD Pt805 & & $E H=885-58,6 \mathrm{pH}$ & 4 & 11 & 0.99 & 30 & $<0.5$ & & $\epsilon$ \\
\hline
\end{tabular}

The previously noted influence of platinum treatment on electrode behaviour is illustrated once again by figure 4 (equations 1 to 3 in table 2 )

Considering the redox equilibrium diagram of platinum (POURBAIX, 1963) the Pt/PtO system could be candidate for an electro-active couple(WHITFIELD, 1974).

The corresponding equations at $25^{\circ} \mathrm{C}$ are :

$\mathrm{Pt}+\mathrm{H}_{2} \mathrm{O}=\mathrm{PtO}+2 \mathrm{H}^{+}+2 \mathrm{e}^{-}$

$\mathrm{E}_{\mathrm{H}}(\mathrm{mV})=980-59.1 \mathrm{pH}$

The polished platinum electrode gives the numerical coefficients of $\mathrm{E}_{\mathrm{H}} \mathrm{vs} \mathrm{pH}$ linear regressions that are closest to those of the preceding theoretical equation. The slightly lower values obtained with purified water from the pilot plant may be probably related to the injection of carbon dioxide gas, which in conditions of acidic $\mathrm{pH}$ slightly reduces the dissolved oxygen concentration.

With water from the MAINCY treatment plant, platinum electrode potential was reduced on average by $58.6 \mathrm{mV}$ while $\mathrm{pH}$ increased by one unit, which is consistent theoretically with an identical exchange of protons and electrons (theoretical value at $23^{\circ} \mathrm{C}=58.7 \mathrm{mV} / \mathrm{pH}$ ).

\section{Dissolved Oxygen}

At constant $\mathrm{pH}$, stabilized electrode potentials and dissolved oxygen concentrations are related by a semi logarithmic relation of the form $\mathrm{E}_{\mathrm{H}}=\mathrm{C}+\mathrm{D} \log \left[\mathrm{O}_{2}\right]$ (HEDUIT and THEVENOT, 1989).

Table 3 presents the results of the measurements performed on the pilot plant.

Table 3. Pilot plant : Relations between potentials reached at the end of the aeration periods and corresponding logarithm of dissolved oxygen concentrations. including equations $6-14$

\begin{tabular}{|c|c|c|c|c|c|c|}
\hline $\begin{array}{l}\text { Sludge } \\
\text { temperature } \\
\left({ }^{\circ} \mathrm{C}\right)\end{array}$ & $\begin{array}{l}\text { Type } \\
\text { of electrode }\end{array}$ & Treatment & $\begin{array}{l}\text { Equations of regression } \\
\qquad \text { lines } \\
\qquad H=C+D \log [02] \\
(m V / N H E) \quad(m g . l-1)\end{array}$ & $\begin{array}{l}\text { Ref. of } \\
\text { equations }\end{array}$ & $n$ & $r^{2}$ \\
\hline 7.7 & $\begin{array}{ll}\text { INGOLD Pt } & 805 \\
\text { INGOLD Pt } & 805\end{array}$ & $\begin{array}{l}\text { Polishing } \\
\text { Rinced distil.water }\end{array}$ & $\begin{array}{l}E H=324+55 \log [02] \\
E H=250+54 \log [02]\end{array}$ & $\begin{array}{l}6 \\
7\end{array}$ & $\begin{array}{l}26 \\
26\end{array}$ & $\begin{array}{l}0.84 \\
0.93\end{array}$ \\
\hline 14.5 & $\begin{array}{ll}\text { INGOLD Pt } & 805 \\
\text { INGOLD Pt } & 805\end{array}$ & $\begin{array}{l}\text { Polishing } \\
\text { Rinced distil.water }\end{array}$ & $\begin{array}{l}E H=412+65 \log [02] \\
E H=262+61 \log [02]\end{array}$ & $\begin{array}{l}8 \\
9\end{array}$ & $\begin{array}{l}9 \\
9\end{array}$ & $\begin{array}{l}0.96 \\
0.96\end{array}$ \\
\hline 20 & $\begin{array}{l}\text { INGOLD Pt } 805 \\
\text { PROLABO } \\
\text { PROLABO }\end{array}$ & $\begin{array}{l}\text { Polishing } \\
\text { Thermal } \\
\text { Th + sulfide ads }\end{array}$ & $\begin{array}{l}E H=405+101 \log [02] \\
E H=378+106 \log [02] \\
E H=295+103 \log [02]\end{array}$ & $\begin{array}{l}10 \\
11 \\
12\end{array}$ & $\begin{array}{l}22 \\
22 \\
22\end{array}$ & $\begin{array}{l}0.95 \\
0.81 \\
0.89\end{array}$ \\
\hline 26 & $\begin{array}{l}\text { INGOLD Pt } 805 \\
\text { INGOLD Pt } 805\end{array}$ & $\begin{array}{l}\text { Polishing } \\
\text { Rinced distil.water }\end{array}$ & $\begin{array}{l}E H=370+61 \log [02] \\
E H=255+68 \log [02]\end{array}$ & $\begin{array}{l}13 \\
14\end{array}$ & $\begin{array}{l}16 \\
16\end{array}$ & $\begin{array}{l}0.96 \\
0.97\end{array}$ \\
\hline
\end{tabular}


The analytical parameters summarizing these experiments are presented in table 4.

Table 4. Analytical parameters relating to the measurements described in table 3.

\begin{tabular}{|c|c|c|c|c|c|c|}
\hline $\begin{array}{c}\text { Sludge temperature } \\
\left({ }^{\circ} \mathrm{C}\right)\end{array}$ & $\begin{array}{c}\text { MLSS } \\
(\mathrm{g} . \mathrm{l}-\mathrm{l})\end{array}$ & $\begin{array}{c}\text { MLVSS } \\
(\%)\end{array}$ & $\mathrm{pH}$ & \multicolumn{3}{|c|}{ Result of effluent analysis } \\
\cline { 5 - 7 } & & & & $\mathrm{NH}_{4}{ }^{+} \mathrm{N}$ & $\mathrm{NO}_{2}{ }^{-}-\mathrm{N}$ & $\mathrm{NO}_{3}{ }^{-}-\mathrm{N}$ \\
\hline 7.7 & 6.9 & 87.0 & 7.65 & 17 & 0.1 & 2 \\
14.5 & 4.55 & 87.4 & 7.6 & 1 & 0.1 & 1.3 \\
20 & 5.6 & 87.9 & 7.55 & 1 & 0.03 & 2 \\
26 & 4.5 & 88.7 & 7.65 & 10 & 0.05 & 0.03 \\
\hline
\end{tabular}

For the measurements made with polished electrodes, the values determined for the $\mathrm{C}$ coefficient ranged between +324 and $+412 \mathrm{mV} / \mathrm{NHE}$, and the $\mathrm{D}$ factor was between 55 and $101 \mathrm{mV} /$ decade.

For the experiments made with platinum electrodes that had simply been rinsed in water, the values for $\mathrm{C}$ were distinctly lower than those that were obtained with polished electrodes (equations 6 and 7, 8 and 9,13 and 14). On the other hand treatment of the metal turned out to have no effect on the D factor (equations 6 to 14).

A contamination of the electrodes that had simply been rinsed in water leads probably to the under-estimation of the potentials in aerated sludge (as compared to polished platinum electrodes).

Figure 5 illustrates the effect of two electrodes treatments (polishing and sulfide adsorption) on their response at different concentrations of dissolved oxygen.

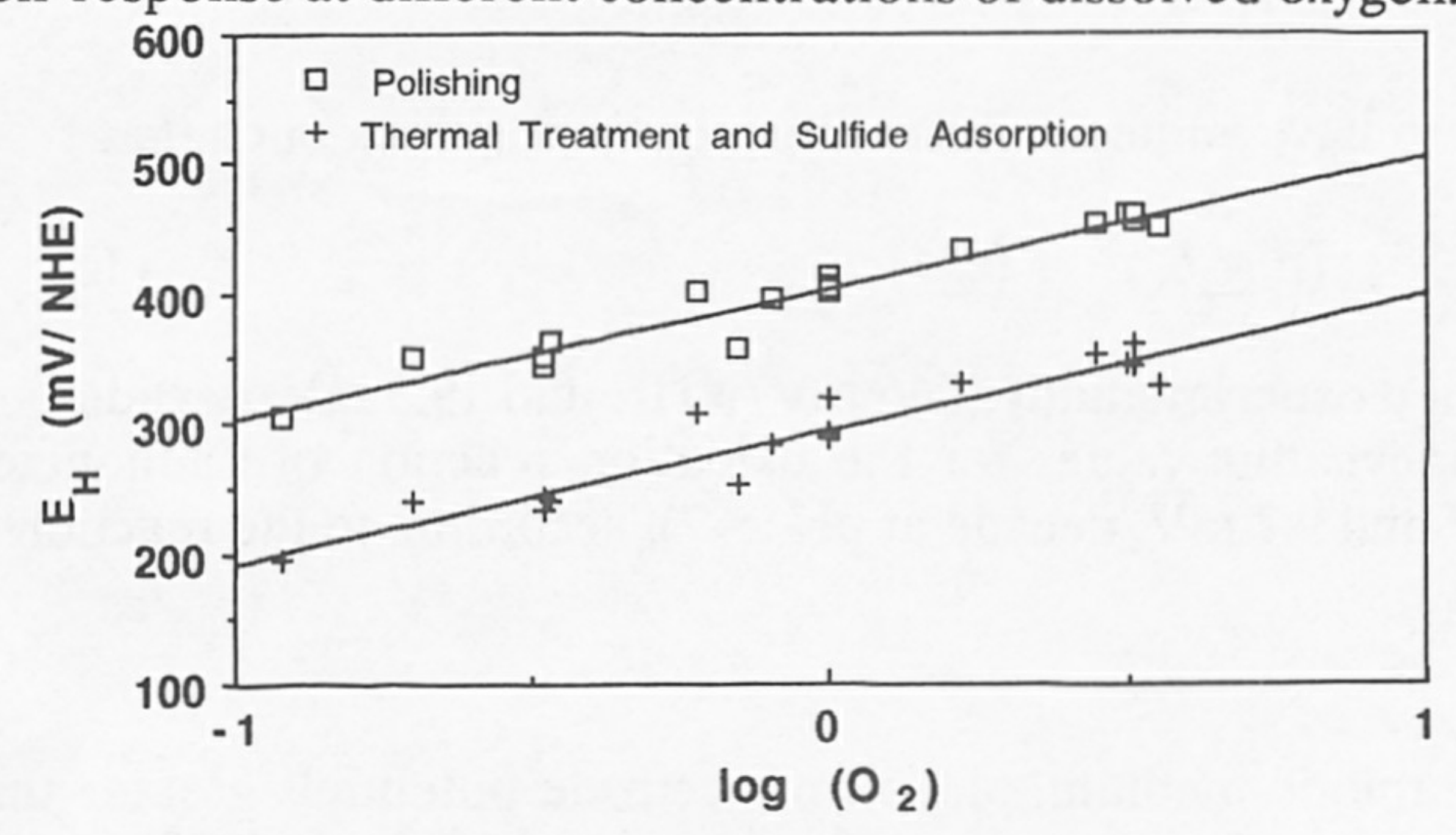

Fig. 5. Linear regression of mean potentials reached at the end of aeration periods against corresponding logarithm of dissolved oxygen concentrations, (equations 10 and 12)

In general terms, dissolved oxygen is electrochemically reduced according to the reaction :

$$
\mathrm{O}_{2}+4 \mathrm{H}^{+}+4 \mathrm{e}^{-} \Rightarrow 2 \mathrm{H}_{2} \mathrm{O}
$$

If the partial oxygen pressure is expressed in atmospheres, its normal potential at $20^{\circ} \mathrm{C}$ is 1.228 V/NHE (MILAZZO, 1969). If the dissolved oxygen content is expressed by weight, the normal potential becomes $1.20 \mathrm{~V} / \mathrm{NHE}$ and the apparent normal potential at $\mathrm{pH} 7.6$ is then 0.76 $\mathrm{V} / \mathrm{NHE}$.

The Nernst equation can then be written :

$$
\mathrm{E}_{\mathrm{H}}=1.2-0.058 \mathrm{pH}+0.015 \log \left[\mathrm{O}_{2}\right]
$$

Where :

$\mathrm{E}_{\mathrm{H}}$ : the oxidation reduction potential/NHE (Volts)

$\log$ : the logarithm base 10

$\left[\mathrm{O}_{2}\right]$ : the dissolved oxygen concentration $\left(\mathrm{mg}^{-1} \mathrm{l}^{-1}\right)$ 
The experimental $\mathrm{C}$ values were always notably lower than the theoretical value $(760 \mathrm{mV}$ at $\mathrm{pH}$ 7.6) and the observed $\mathrm{C}$ factors greater than the theoretical slope of the Nernst equation for the reduction of dissolved oxygen ( $15 \mathrm{mV} /$ decade).

\section{Mineral forms of nitrogen $\left(\mathrm{NH}_{4}^{+}, \mathrm{NO}_{2}^{-}, \mathrm{NO}_{3}^{-}\right)$}

Measurements on the pilot plant at $7.7^{\circ} \mathrm{C}$ and $20^{\circ} \mathrm{C}$, made at the same time as the potential and oxygen measurements, did not lead to definitive results because of the concomitant evolution of the concentrations of dissolved oxygen and nitric and ammoniacal forms of nitrogen. Unable thus to bring out the direct effect of mineral forms of nitrogen on platinum electrode potential, we resorted to an abiotic medium under stabilized conditions of $\mathrm{pH}$, dissolved oxygen, and temperature. The mean values of the potentials measured are presented in figure 6 as a function of the logarithms of the ratios $\left[\mathrm{NO}_{2}^{-}\right] /\left[\mathrm{NH}_{4}{ }^{+}\right]$.

Fig. 6. Stabilized potentials of polished platinum electrodes as a function of the logarithm of the ratio of the corresponding $\left[\mathrm{NO}_{2}^{-}\right]$and $\left[\mathrm{NH}_{4}{ }^{+}\right]$concentrations in a pH 7 phosphate buffer

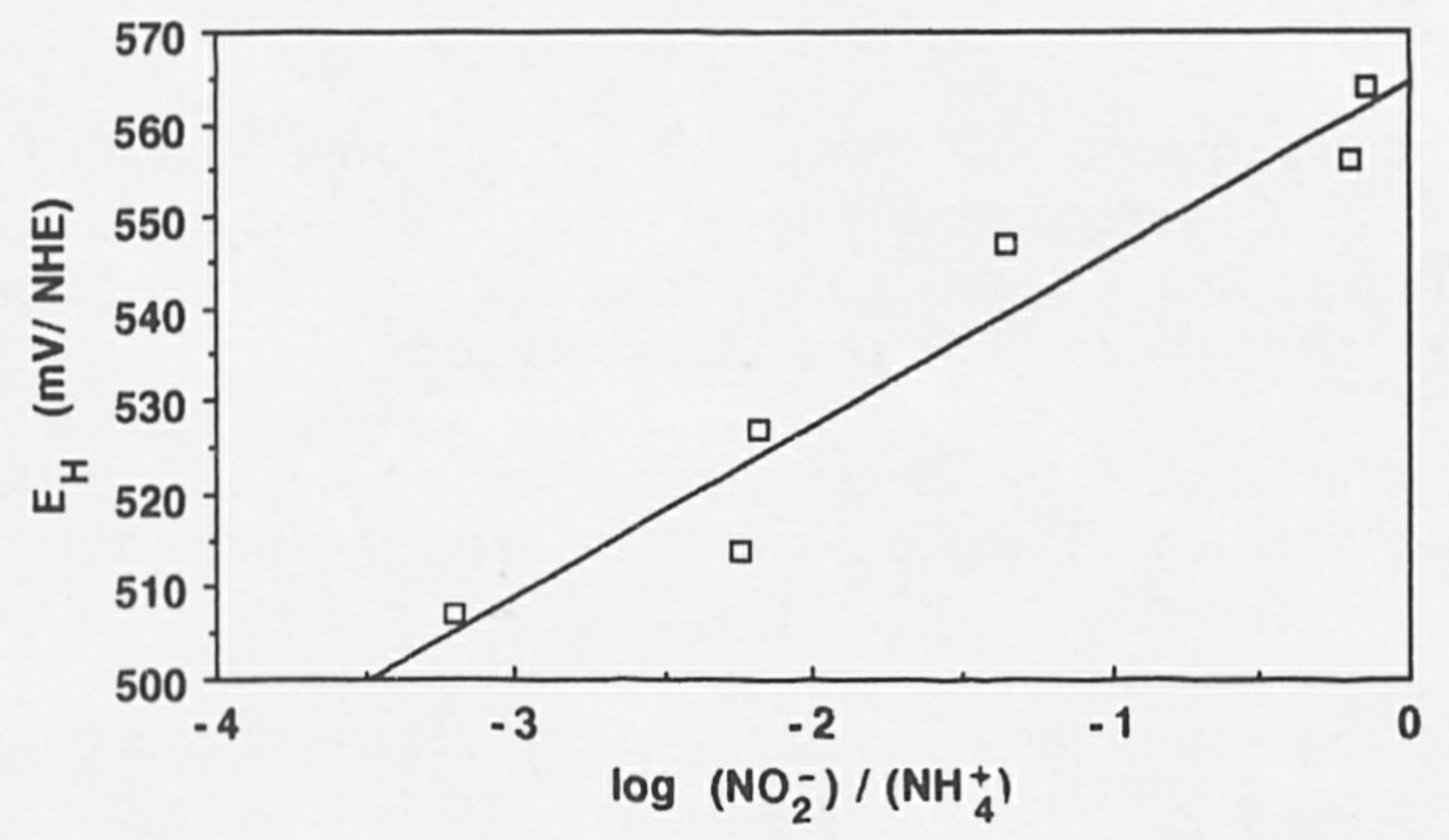

The $\left[\mathrm{NO}_{2}^{-}\right] /\left[\mathrm{NH}_{4}{ }^{+}\right]$couple proves to have a linear effect on electrode response, such that :

$$
\mathrm{E}_{\mathrm{H}}=566+19.3 \log \left[\mathrm{NO}_{2}^{-}\right] /\left[\mathrm{NH}_{4}{ }^{+}\right] \quad\left(\mathrm{n}=6, \mathrm{r}^{2}=0.94\right)
$$

The values of the coefficients obtained experimentally $(566 \mathrm{mV} / \mathrm{NHE}$ and $19.3 \mathrm{mV} /$ decade) are, however, quite far from the thermodynamic values for the oxidation reaction of ammoniacal nitrogen into nitrites alone $(365 \mathrm{mV}$ and $9.7 \mathrm{mV} /$ decade at $\mathrm{pH}=7)$, according to the reaction :

$\mathrm{NH}_{4}^{+}+2 \mathrm{H}_{2} \mathrm{O} \rightleftharpoons \mathrm{NO}_{2}^{-}+8 \mathrm{H}^{+}+6 \mathrm{e}^{-}$.

It is interesting to note that in this abiotic medium, platinum electrode potentials greater than $500 \mathrm{mV} / \mathrm{NHE}$ are obtained for very high concentrations of ammoniacal nitrogen $\left(270 \mathrm{mg} . \mathrm{l}^{-1}\right)$, which is contrary to observations made in activated sludge.

Under these experimental conditions, the $\left[\mathrm{NO}_{3}{ }^{-}\right] /\left[\mathrm{NO}_{2}^{-}\right]$system has no further effect on platinum electrode potential beyond a concentration of $\mathrm{NO}_{3}^{-}-\mathrm{N}$ of $1 \mathrm{mg} \cdot \mathrm{l}^{-1}$ in purified water containing $0.15 \mathrm{mg} \cdot 1^{-1}$ of $\mathrm{NO}_{2}^{--\mathrm{N}}(\mathrm{EH}=+585 \mathrm{mV} / \mathrm{NHE})$. For lower $\mathrm{NO}_{3}^{--\mathrm{N}}$ concentration, the potential decreases slowly $\left(\mathrm{EH}=+560 \mathrm{mV} / \mathrm{NHE}\right.$ for $\left.\mathrm{NO}_{3}^{-}-\mathrm{N}=0.1 \mathrm{mg}^{-1}{ }^{-1}\right)$.

\section{CONCLUSION}

The platinum electrode potential in activated sludge is strongly dependent on the initial treatment of the metal and thus on its surface characteristics. The platinum does not behave like an inert metal : depending on whether the electrode has been first polished, annealed or in contact with sulfide, its behaviour will be quite different. Polishing the platinum with abrasive bands confers good stability on the electrode response. A drift of the electrode potential occurs very slowly after a thermal treatment in an activated sludge periodically submitted to light anoxic 
conditions. The contamination of platinum by sulfide leads to an under estimation of the potentials in aerated activated sludge as compared to a clean electrode response. The initial characteristics of the metal are recovered subsequently to a proper thermic or mechanical treatment. In anaerobic conditions, deviations of stabilized potentials are very slight (less than $10 \mathrm{mV}$ ) among platinum electrodes that have undergone identical controlled treatments.

In purified water that is saturated with dissolved oxygen, the potential of a polished platinum electrode diminishes by $58.6 \mathrm{mV}$ at $23^{\circ} \mathrm{C}$ while $\mathrm{pH}$ increases by one unit. This response is consistent with the theory of an identical exchange of protons and electrons. Electrode potential $\left(\mathrm{E}_{\mathrm{H}}\right)$ might thus be governed by the $\mathrm{Pt} / \mathrm{PtO}$ system, even though in the $\mathrm{E}_{\mathrm{H}}=\mathrm{A}-\mathrm{B} \cdot \mathrm{pH}$ relation that was established, the A coefficient is lower than the apparent normal potential of the $\mathrm{Pt} / \mathrm{PtO}$ system.

The measurements made on the pilot plant at different temperatures confirm that, under stabilized conditions, electrode potential $\left(\mathrm{E}_{\mathrm{H}}\right)$ and dissolved oxygen concentration $\left[\mathrm{O}_{2}\right]$ are linked by a relation of the form $\mathrm{E}_{\mathrm{H}}=\mathrm{C}+\mathrm{D} \log \left[\mathrm{O}_{2}\right]$. $\mathrm{C}$ (which depends on the treatment of the electrode) is always less than the apparent normal potential corresponding to the electrochemical reduction of dissolved oxygen $\left(\mathrm{O}_{2} / \mathrm{OH}^{-}\right.$system). It seems to be highest when nitrification is most extreme. $\mathrm{D}$ is independent of electrode treatment and is always greater than the theoretical slope of the Nernst equation for the reduction of dissolved oxygen (15 $\mathrm{mV} /$ decade). Its value falls in the $55-100 \mathrm{mV} /$ decade range.

The nitrite/ammonium couple has a direct influence on platinum electrode potential at concentrations in the range of those encountered in activated sludge : in an abiotic medium saturated in dissolved oxygen, at $\mathrm{pH} 7$ and at $23^{\circ} \mathrm{C}$, these two variables can be related by an equation of the form $\mathrm{E}_{\mathrm{H}}=\mathrm{E}+\mathrm{F} \log \left[\mathrm{NO}_{2}^{-}\right] /\left[\mathrm{NH}_{4}{ }^{+}\right]$. The measured values of the $\mathrm{E}$ coefficient and the $\mathrm{F}$ factor, $+566 \mathrm{mV} / \mathrm{NHE}$ and $19.3 \mathrm{mV} /$ decade, are quite different from the thermodynamic values for the oxidation reaction of the ammonium ion into nitrites $(+365$ $\mathrm{mV} / \mathrm{NHE}$ and $9.7 \mathrm{mV} /$ decade).

The nitrate/nitrite couple, on the other hand, does not seem to have an important effect on potential for nitrate concentrations greater than $1 \mathrm{mg} \cdot \mathrm{l}^{-1}$ (if $\left[\mathrm{NO}_{2}^{-}-\mathrm{N}\right]=0.15 \mathrm{mg} \cdot \mathrm{l}^{-1}$ ).

A stabilized platinum electrode potential can thus be governed by various different species : $\mathrm{pH}$ (in all likelihood, through the $\mathrm{Pt} / \mathrm{PtO}$ system), dissolved oxygen $\left(\mathrm{O}_{2} / \mathrm{OH}^{-}\right.$system), $\mathrm{NO}_{2}^{-} / \mathrm{NH}_{4}{ }^{+}$ and $\mathrm{NO}_{3}{ }^{-} / \mathrm{NO}_{2}{ }^{-}$systems and this list is obviously not exhaustive. The experimental values of the coefficients relating electrode potential to these different components are always significantly different from the corresponding thermodynamic values. The platinum is thus not in equilibrium with the dissolved substances cited above, probably because the reactions at the interfaces are too slow.

A stabilized potential on a platinum electrode in activated sludge is therefore probably a mixed potential in which adsorbed substances play an important role. This potential nevertheless seems to provide an overall indication of the redox state of the bacterial culture, so knowledge of it could be useful for conducting the operation of biological treatment plants.

\section{REFERENCES}

CHARPENTIER J., FLORENTZ M., DAVID G. (1987). Oxidation reduction potential (ORP) regulation : A way to optimise pollution removal and energy savings in the low activated sludge process. Wat. Sci. Tech., 19(3/4), 645-655. 
CHARPENTIER J., GODART H., MARTIN G., MOGNO Y. (1989). Oxidation reduction potential (ORP) regulation as a way to optimize aeration and $\mathrm{C}, \mathrm{N}$ and $\mathrm{P}$ removal : experimental basin and various full-scale examples. Wat. Sci. Tech. 21.(10/11) 1209-1223.

GOLDSMITH S., COLE J.A., FORSTER C.F. (1984). Changes in the redox potential and malate dehydrogenase activity of activated sludge. Environ. Technol. Lett., 5, 219-226.

HEDUIT A., COQUERY M., THEVENOT D.R., (1987). Potentiel d'oxydo-réduction en épuration biologique - méthode de mesure et applications. T.S.M. 5, 219226.

HEDUIT A., LECLERC L.A., SINTES L., THEVENOT D.R., (1988). Perspectives de maîtrise des processus de nitrification et de dénitrification dans les boues activées à l'aide du potentiel d'oxydo-réduction. Wat. Supply 6 275-285.

HEDUIT A., THEVENOT D.R. (1989). Relation between redox potential and oxygen levels in activated sludge reactors. Wat. Sci. Tech. 21(8/9), 947-956.

KOCH F.A., OLDHAM W.K. (1985). ORP : a tool for monitoring control and optimization of biological nutrient removal systems. Wat. Sci. Tech., 17(11/12), 259-281.

MILAZZO C. (1969). Electrochimie - Dunod ed. Paris, 426 p.

POURBAIX M. (1963). Atlas thermodynamique à $25^{\circ} \mathrm{C}$. Gauthiers Villars Ed., Paris.

VIRLOGET F. (1991). Intérêt pratique de la mesure redox pour une élimination optimale des nutriments. Proc. 5ème congr. AGHTM, Annecy 115-139.

WHITFIELD M. (1974). Thermodynamic limitations on the use of platinum electrode in Eh measurements. Limn Oceanogr., 19, 857-865. 